\title{
Research
}

\section{Making Investments in Dryland Development Work: Participatory Scenario Planning in the Makanya Catchment, Tanzania}

\author{
$\underline{\text { Elin I. Enfors }}^{1}, \underline{\text { Line J. Gordon }}^{1,2}$, Garry D. Peterson $^{2,3}$, and Deborah Bossio $^{4}$
}

\begin{abstract}
The agro-ecosystems of semi-arid and dry sub-humid SSA are inherently dynamic. At this point in time they are also experiencing a series of complex social-ecological changes that make their future even more uncertain. To ensure that development investments made today in the small-scale farming systems that dominate these regions make sense also in a long-term perspective they should benefit the local communities over a range of potential futures. We applied a participatory scenario planning approach to a smallholder farming community in semi-arid Tanzania, exploring four alternative development trajectories for the area, to increase the robustness of current investments in small-scale water system technologies. We found that water system technologies will be important across a number of possible futures, but that the most relevant target of these innovations, e.g., staple- versus cash-crop production, or individual- versus community-managed systems, differs. We argue that building capacity for experimentation among farmers is key to upgrading their farming systems, as this will generate benefits over a range of alternative futures. Furthermore, we found it to be essential across a range of scenarios to analyze the system-level impact of proposed interventions for successful investments in water system technologies. We conclude that although the method presents some challenges, participatory scenario planning is a useful tool for integrating research and development projects in the larger context, asit increases the understanding of events and processes that may either challenge the project or provide opportunities for it.
\end{abstract}

Key Words: dryland regions; future; investments; participatory scenario planning; small-scale farming; sub-Saharan Africa; uncertainty; water system technologies

\section{INTRODUCTION}

Governments, scientists, and NGOs are currently making large efforts to improve productivity in the small-scale farming systems that constitute the main livelihood source in sub-Saharan Africa (SSA), as this is seen as one of the most realistic routes to food security, poverty alleviation, and development in the region (Food and Agriculture Organization (FAO)/New Partnership for Africa's Development (NEPAD) 2002, Diao et al. 2007). Current farming systems are primarily rainfed and non-mechanized, use very low levels of external inputs, and yield as little as 1 ton/ha. A key constraint, especially in the semiarid and dry subhumid parts of SSA, is water availability (Falkenmark and Rockström 2004). Although the conventional cure has been the development of large-scale irrigation, recent attempts to overcome crop water deficits have increasingly focused on small-scale solutions, including rainwater harvesting for supplemental irrigation, conservation farming techniques, and other types of small-scale water system innovations (Falkenmark and Rockström 2004, United Nations Development Programme (UNDP) 2006, Comprehensive Assessment of Water Management in Agriculture 2007). This type of technology appears to have significant potential to stabilize and improve yields in small-scale farming systems (Fox and Rockström 2003, Liu et al. 2005, Kahinda et al. 2007, Makurira et al. 2007), and the interest in water system innovations as an option for semiarid and subhumid SSA is currently high (Peacock et al. 2007).

\footnotetext{
${ }^{1}$ Natural Resources Management, Department of Systems Ecology, Stockholm University, Sweden, ${ }^{2}$ Stockholm Resilience Center, Stockholm University, Sweden, ${ }^{3}$ Department of Geography and McGill School of Environment, McGill University, Canada, ${ }^{4}$ International Water Management Institute (IWMI), Sri Lanka
} 
Dryland agro-ecosystems are, however, inherently dynamic, with rapid rates of social and ecological change, making it difficult to predict their future development (Mortimore 2005, Reynolds et al. 2007, Gordon et al. 2008). The rainfall variability generates large spatial and temporal variations in productivity (Millennium Ecosystem Assessment 2005), and a range of other processes, including urbanization, increasing connectedness, market developments, and changing values, have driven recent changes in traditional production and livelihood systems (cf. Bryceson 1996). The strong pressure for rapid transformation to reach the Millennium Development Goals by 2015 further increases the uncertainty surrounding the future of these agro-ecosystems. If not accounting for these processes of change, there is a risk that current development interventions will be outdated before they are implemented. Past examples of this include the promotion of specific cash crops where the market demand has later declined rapidly. Similarly, "silver bullet" approaches focusing on single technologies have frequently failed, as the rate of technological change has been higher than the rate of adoption. A well-known example is the treadle pump that has been widely promoted by NGOs in both Africa and Asia over the past two decades, but which is becoming redundant because of the small motorized pumps entering the market and filling the need for water lifting with far less labor (Shah et al. 2000). Consequently, to ensure that investments made today to upgrade small-scale rainfed farming in dryland SSA also are useful over a long-term perspective, they should be able to benefit the local communities over a range of potential development trajectories.

A way to explore the relative usefulness of specific development and applied research projects under various future conditions is to use scenario planning (Wack 1985, Wollenberg et al. 2000a, Peterson et al. 2003). This can help identify opportunities and risks that a community might face in relation to planned interventions and suggest management strategies to respond to these situations. We used a scenario-planning approach for a smallholder farming community in semiarid Tanzania, focusing particularly on how current investments in smallscale water system technologies could be made more robust (the rationale behind the focus is expanded on in Appendix 1). The study was conducted in the Makanya catchment where a research and development project concerning smallholder water system innovations has been in progress since 2004 (Rockström et al. 2004, Bhatt et al. 2006).

The paper begins with a short overview of scenario planning as a tool for social-ecological assessments and decision making, zooming in on its usefulness in the dryland development context. This is followed by an introduction to the Makanya catchment and a description of the scenarioplanning process that was employed there. We then present four alternative scenarios of the future of Makanya, discussing the role of small-scale farming and associated investments in each of them. We conclude by suggesting how current water-related investments in small-scale agriculture could become more robust, and by highlighting lessons learned from the scenario planning approach in Makanya.

\section{BACKGROUND}

\section{What is Scenario Planning?}

Scenario planning is a systematic method for creatively analyzing complex futures. A scenario is an internally consistent and realistic narrative about the future of a region that is informed by existing conditions and processes, while also factoring in future potential drivers of development (Gallopin et al. 1997, Raskin 2005). Scenario planning uses contrasts among several plausible futures to highlight relationships between environmental factors, management choices, and system dynamics in a way that can inform decision making (Peterson et al. 2003). Central to the process is identifying key drivers of change for the considered system, important uncertainties, and system feedback processes that could strengthen or weaken particular development trajectories (van der Heijden 1996, Gallopin et al. 1997). Scenario planning can be used to identify future opportunities and threats, and thereby help navigating social-ecological systems along more desirable trajectories (Peterson et al. 2003). An advantage of scenario planning is that it can incorporate a wealth of information from a variety of disciplines, and although dealing with complex system dynamics, the outcome is often easily accessible for scientists as well as policy makers and lay people (Kok et al. 2007).

Scenario-planning exercises can be participatory or expert led to varying degrees (van Notten et al. 2003) and performed from local to global scales, or 
sometimes across scales (Biggs et al. 2007). Scenarios have been used in a number of expert-led regional-scale agricultural planning exercises, for example in Iowa (Santelmann et al. 2004), Denmark (Tress and Tress 2003), the Willamette River Basin in Oregon (Baker et al. 2004), and the San Pedro River Basin across the USA-Mexico border (Steinitz et al. 2003). However, few examples exist where participatory scenario planning has been used with the specific aim of improving the robustness of particular development interventions (Wollenberg et al. 2000a). In this paper, we provide such an example by applying participatory scenario planning to the social-ecological analysis of agricultural development in the Makanya catchment. If organized and applied well, this type of scenario-planning process can become a powerful tool for learning, consensus building, and public action, which can make local communities better at preparing for, adapting to, and shaping their future (Wollenberg et al. 2000a, Peterson 2007).

\section{Scenario Planning in the Dryland Development Context}

There are currently a number of on-going social, economic, and environmental processes, whose nature is dramatic and whose outcome uncertain, driving change in semiarid and dry subhumid SSA. Although there are strong forces at multiple levels working for development, large parts of these regions are marginalized, lacking infrastructure, public services, and market access, and lag far behind the rest of the world in human development indicators (UNDP 2007). The vast majority of the population live from small-scale farming and livestock keeping, and their livelihood security is, therefore, intimately linked with the local agroecological productivity (World Resources Institute (WRI) 2005). The productivity is, however, limited both by the challenging hydroclimate and by land degradation (Millennium Ecosystem Assessment 2005). Over the past decade (s), non-farm income sources have become increasingly important for smallholders in these regions (Ellis 1998, Bryceson 2002). This development is driven both by push factors, such as climate uncertainty and lack of fertile land, and by pull factors, such as market developments and changing preferences. One reason for the latter is that the investments made in education over the past decades have created a young generation that is much more educated than their parents, and consequently, has different opportunities and desires (Bryceson 1996). Although these regions still are predominantly rural, with less than $30 \%$ of the population living in urban areas (UNDP 2007), the urban population is expected to increase to $50 \%$ by 2030 (United Nations department of Economic and Social Affairs (UNESA) 2008). Finally, as some of the aftermath from the 1980s' economic crises and subsequent structural adjustment programs has settled, many of the countries in SSA have managed to maintain a high annual economic growth rate at around 5\%-6\% over the past years (World Bank 2007). Although this is remarkable, it should also be noted that this is the only region in the world where the number of extremely poor people has increased over the past 15 years. The high level of uncertainty about the future, in combination with the poverty-induced vulnerability among the population, makes it particularly important to design current development interventions carefully. In this context, scenario planning can be useful as a tool for exploring how different interventions might play out over different futures.

\section{THE CASE STUDY}

\section{Site Description of the Makanya Catchment}

The Makanya catchment is located in the South Pare Mountains, Same District, Kilimanjaro region, Tanzania (Fig. 1). The catchment is similar to other rural areas in semiarid SSA in that it has experienced a series of dramatic changes over the past decades that suggest that several alternative future development paths are possible (Fig. 2).

The catchment covers $320 \mathrm{~km}^{2}$ and hosts some 15 rural villages. It stretches from densely populated highland areas, via a vast mid-slope area, down to the plains, where the Dar es Salaam-Arusha highway passes, a large sisal plantation operates, and the village of Makanya is located. Between 35 000-40 000 people live in the area, and the population grows at $1.6 \%$ per year (The United Republic of Tanzania 2002). The dominant ethnic group is the "Pare," with about half the population being Christian and the other half Muslim. The adult literacy rate lies at $80 \%$ (The United Republic of Tanzania 2005a).

The climate is semiarid to dry subhumid, and the rainfall pattern bimodal. Annual average precipitation 
Fig. 1. The Makanya catchment. The left map shows the Makanya catchment on a satellite-image background from Google Earth/Earthsat 2005. The right map shows the position of the catchment in Northeastern Tanzania.
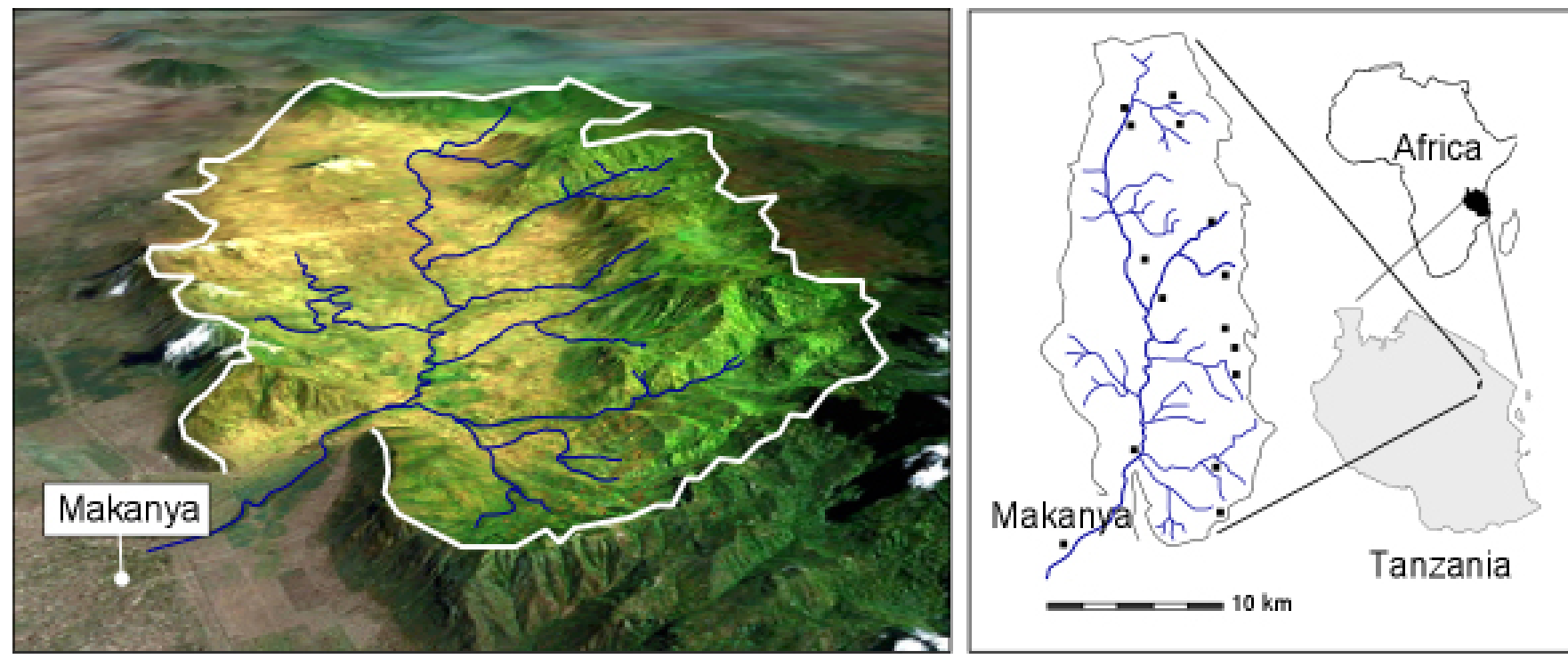

ranges from $500 \mathrm{~mm}$ in the lowlands to about 1000 $\mathrm{mm}$ in the highlands, but the rainfall is highly variable both between and within years and the variability has increased over the past decades (Enfors and Gordon 2007). Small-scale farming, that is non-mechanized and involves few external inputs, is the principal food and income source. Farmers grow maize for subsistence, with harvests averaging just above 1 ton/ha (Food and Agriculture Organization (FAO) 2008), and vegetables as cash crops. In the highlands, agriculture is practiced throughout the year supported by an indigenous supplemental irrigation system (the "Ndiva" system). At mid-elevations in the catchment, farming is confined to the rainy seasons despite "Ndiva" irrigation. Downstream in the catchment, rainfall is too low for crop production and farming is supported by a local spate-irrigation system. Livestock keeping constitutes an important additional livelihood source here. Farmers in all parts of the catchment perceive lack of water as a major constraint to crop production. Despite a significant expansion of cultivated areas over the past decades, relatively large areas of bush still exist in the Makanya catchment. The bushland supplies farmers with a range of provisioning ecosystem services, such as fodder for livestock, firewood, and construction materials. Although local people share the opinion that this resource base is degrading, this support is still very important especially when the crops fail (Enfors and Gordon 2008). For more details on the catchment's historical development see Enfors and Gordon (2007) and Fig. 2.

The farmers of the Makanya catchment are poor. In 2000, their average cash income was estimated at 149000 Tsh per capita, which at the time corresponded to US\$150 (Same District Council 2006). Although most households in the catchment consider farming and livestock keeping to be their main income sources, a range of non-farm income sources, including petty trade, wage labor, remittances, and temporal labor migration also contribute income. Lately, interest in mining (of, e. g., gypsum, gemstones, and iron ore) has increased, and some companies have started prospecting in the catchment. Although many parts of the catchment are inaccessible, infrastructure has improved over the past few years, and there are daily transports to Same, Moshi, and Arusha. Large parts of the catchment have also received cellphone network coverage recently, and although most households still lack electricity, many farmers own cellular phones. Despite these developments, market access 
Fig. 2. Schematic illustration of the development path in Makanya catchment. The highlighted line symbolizes Makanya's development path over the past century. The other lines symbolize alternative pathways that may have been possible. Social, political, economic, and environmental events and processes shape the development trajectories of social-ecological systems, determining which path will be followed and when a system will change trajectory. Some examples of important events that have shaped Makanya's development are shown in the boxes. Black arrows symbolize points in time when the development has changed its course, gray arrows symbolize a continuation of existing pathway, and white arrows symbolize alternative pathways that may have been possible but were not followed. Over the past decade(s), a number of dramatic changes have been taking place in Makanya, raising questions about the future development trajectory in the catchment, as indicated by the arrows pointing toward year 2030.

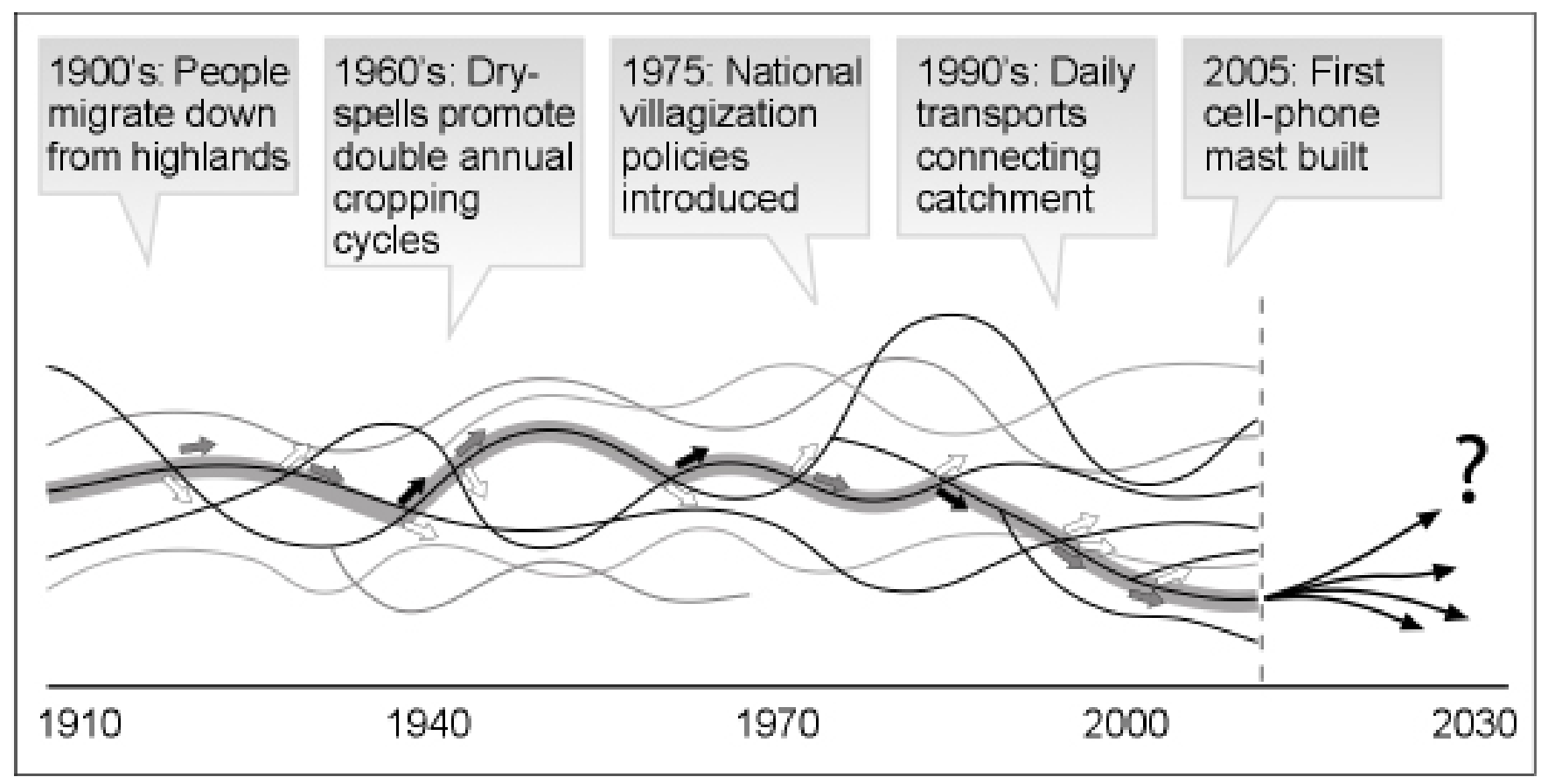

is still limited for the smallholders, and their farm produce is mainly sold at local markets, a consequence being that agricultural investments yield low returns. More than 10 NGOs are active in the area, working on issues such as crop production and animal husbandry, marketing of agricultural products, water provisioning, education, and health. Parallel to the District council and village governments, these organizations are important actors driving community development in the catchment.

Table 1 presents some official statistics on current development trends in Tanzania, including data on economic development, trends in human welfare, demography, projected climate change, and prospects for smallholder farming. Because these data are not available at the local level, we have interpreted the implications of these trends for the Makanya catchment in the last two columns of Table 1. The extrapolation to year 2030 in column five serves to demonstrate that substantial changes can be expected in the area in the near future. For example, with current population growth and onfarm productivity, the amount of farming land per capita would be too small to serve as a base for farming livelihoods in 2030. 
Table 1. Official statistics on current development trends in Tanzania. In the two last columns, we have interpreted the implications of these trends for Makanya catchment. Sources: The World Bank (2007), UNDP (2007), IPCC (Boko et al. 2007, Christensen et al. 2007, Easterling et al. 2007), and the United Republic of Tanzania (2001, 2002, 2005a, 2005b, 2006). Regional-, district-, and local-level data also come from FAO (2008), Same District Council (2006), and Enfors and Gordon (2007).

\begin{tabular}{|c|c|c|c|c|}
\hline & Indicator & National-level statistics & $\begin{array}{l}\text { Current implications for } \\
\text { Makanya }\end{array}$ & $\begin{array}{l}\text { Implications for Makanya 2030: } \\
\text { direct projection of current trends }\end{array}$ \\
\hline \multirow[t]{2}{*}{$\begin{array}{l}\text { Economic } \\
\text { Development }\end{array}$} & Annual GDP growth & $\begin{array}{l}\text { On average } 6.3 \% \\
\text { between } 2000-2006, \\
\text { projected to increase to } \\
7.9 \% \text { by } 2009\end{array}$ & $\begin{array}{l}\text { Investments in } \\
\text { infrastructure and } \\
\text { secondary education }\end{array}$ & - \\
\hline & Per capita income & US\$350 in 2006 & $\begin{array}{l}\text { Below national average, } \\
\text { US } \$ 150 \text { in } 2002\end{array}$ & - \\
\hline \multirow[t]{3}{*}{ Human welfare } & $\begin{array}{l}\text { Poverty (\% of population } \\
\text { below the basic needs } \\
\text { poverty line) }\end{array}$ & $\begin{array}{l}31 \% \text { in } 2005, \text { projected to } \\
\text { be } 27 \% \text { in } 2010\end{array}$ & $\begin{array}{l}\text { About } 11000 \text { people in } \\
\text { Makanya }\end{array}$ & $\begin{array}{l}7000-9000 \text { people, depending on } \\
\text { population growth }\end{array}$ \\
\hline & $\begin{array}{l}\text { Prevalence of } \\
\text { malnourishment }\end{array}$ & $44 \%$ in $2002-2004$ & $\begin{array}{l}\text { Food shortages during } \\
2005-2006 \text { drought }\end{array}$ & - \\
\hline & Adult literacy rate & $\begin{array}{l}59 \% \text { in } 1985-1994,69 \% \\
\text { in } 1995-2005\end{array}$ & $\begin{array}{l}>80 \% \text { in Kilimanjaro } \\
\text { region }\end{array}$ & Increasing \\
\hline \multirow[t]{2}{*}{ Demography } & $\begin{array}{l}\text { Annual predicted } \\
\text { population growth rate }\end{array}$ & $\begin{array}{l}2.4 \% 2005-2015 \\
\text { (urban growth rate at } \\
4.6 \% \text { ) }\end{array}$ & $\begin{array}{l}35000 \text { people, the regional } \\
\text { population growth is about } \\
1.6 \% \text { annually }\end{array}$ & $\begin{array}{l}\text { With } 1.6 \% \text { growth, the population } \\
\text { will be } 52000 \text {, with } 2.4 \% \text { it will be } \\
63000\end{array}$ \\
\hline & $\begin{array}{l}\text { Urban population (\% of } \\
\text { total population) }\end{array}$ & $\begin{array}{l}24.2 \% \text { in } 2005, \text { projected } \\
\text { to } 28.9 \% \text { in } 2015\end{array}$ & $\begin{array}{l}\text { Young people are moving } \\
\text { to towns }\end{array}$ & $\begin{array}{l}\text { Potentially changing demographic } \\
\text { structure, dominated by older } \\
\text { people and children }\end{array}$ \\
\hline \multirow[t]{3}{*}{ Climate change } & Temperature & $\begin{array}{l}\text { Increases of } 2.5-3.5^{\circ} \mathrm{C} \\
\text { likely during the } 21^{\text {st }} \\
\text { century }\end{array}$ & - & - \\
\hline & Rainfall levels & $\begin{array}{l}\text { Increases up to } 15 \% \\
\text { expected during the } 21^{\text {st }} \\
\text { century (projections } \\
\text { consistent across most } \\
\text { IPCC scenarios) }\end{array}$ & $\begin{array}{l}562 \mathrm{~mm} / \text { year, with large } \\
\text { variations }\end{array}$ & - \\
\hline & Extreme events & $\begin{array}{l}\text { Rainfall intensity likely } \\
\text { increasing, having a clear } \\
\text { negative impact on } \\
\text { agricultural productivity }\end{array}$ & $\begin{array}{l}\text { Dry-spell frequency } \\
\text { steadily increasing from } \\
\text { 1950s. After 1980, four out } \\
\text { of five "Masika" seasons } \\
\text { have a dry spell of } 21 \text { days } \\
\text { or longer }\end{array}$ & $\begin{array}{l}\text { >four-five seasons with severe dry } \\
\text { spells }\end{array}$ \\
\hline \multirow[t]{2}{*}{$\begin{array}{l}\text { Agricultural } \\
\text { development }\end{array}$} & Yields & $\begin{array}{l}\text { Potential maize yield } \\
\text { reductions of up to } 20 \% \\
\text { during the } 21^{\text {st }} \text { century } \\
\text { due to temperature } \\
\text { changes alone }\end{array}$ & $\begin{array}{l}1.14 \text { ton/ha on average, but } \\
\text { drought-induced harvest } \\
\text { losses common }\end{array}$ & $\begin{array}{l}0.9-1 \text { ton/ha providing no } \\
\text { improvements, may be declining } \\
\text { more if trend of increasing dry- } \\
\text { spell frequency continues }\end{array}$ \\
\hline & $\begin{array}{l}\text { Available farmland per } \\
\text { capita }\end{array}$ & $\begin{array}{l}\text { Average farm size } 2.3 \text { ha } \\
\text { per household, of which } \\
80 \% \text { is in use }\end{array}$ & $\begin{array}{l}2.5 \text { ha per household }(0.5 \\
\text { ha per capita), including } \\
\text { fallow land }\end{array}$ & $\begin{array}{l}0.28-0.34 \text { ha per capita depending } \\
\text { on population growth, taking } \\
\text { agricultural land expansion into } \\
\text { account it would be } 0.33-0.39 \text { ha }\end{array}$ \\
\hline
\end{tabular}


$\%$ of population living Between $70 \%-80 \%$, from small-scale farming decreasing

Average annual change in $-1.0 \%(1990-2005)$ forested area

Agricultural policy
Focus on transformation of subsistence to commercial farming
Estimated to be higher than Decreasing $80 \%$

Bushland covers $37 \%$ of the catchment

Decrease to $28 \%$ of the catchment

Support for vegetablegrowing projects and foodprocessing projects

\section{The Scenario-Planning Process}

The objective of the scenario-planning exercise in Makanya was to develop four alternative scenarios for the catchment's future, describing in qualitative terms agroecological conditions, livelihood sources, and lifestyles in the area around year 2030. We used a scenario workshop methodology based on that developed during the Millennium Ecosystem Assessment (Bennett and Zurek 2006).

To develop the scenarios, a 2-day workshop was held in Makanya in December 2006, with a range of local stakeholders. In total, 32 people took part in the workshop (23 farmers from the catchment, three chairmen from different villages in the catchment, four local extension workers, one representative of the District council, and one representative of the major NGO in the area). These participants were chosen to include a variety of local perspectives in the scenarios while still maintaining focus on the farmers' perceptions. The workshop was facilitated in English, with three interpreters working in parallel to translate between English and Swahili. Participants' qualitative understanding of the conditions and trends in the region corresponded to the data in Table 1 fairly well, giving us confidence that the scenarios emerged from a shared understanding of the current situation of the Makanya catchment.

In the first step of the scenario-planning process, the participants were asked to discuss and list factors that they thought would be important drivers of change in the area in the coming 25 years. This was followed by a ranking exercise, where these factors were ranked both after their relative importance and after their level of uncertainty (Table 2). A driving force was classified as uncertain either if many participants were uncertain about how it would develop (e.g., will the national economy improve or deteriorate?) or if they disagreed about how it would develop. The drivers that are perceived as both important and uncertain are particularly interesting to explore in the scenarios. Having completed the ranking, five such factors were identified. These were combined in four different ways to form the starting points for the four alternative scenarios (cf. Wollenberg et al. 2000b). We settled on four scenarios, following the advice of many scenario practitioners, to have a fairly small and manageable set, while avoiding the risk that three scenarios would result in a good, medium, and bad one (see, e.g., Wollenberg et al. 2000b). As seen in Table 3, not all driving forces that were classified as important and uncertain are included in all scenarios. This is because our objective was to explore the potential outcome of key driving forces that were thought to be particularly interesting. Having agreed on the starting points, the storylines were developed in smaller groups in an iterative process until they were reasonably consistent.

After the workshop, we edited and analyzed the scenarios. Because the groups had structured their storylines differently during the workshop, a number of broad themes that were common to all scenarios were identified (listed in Table 4). To clarify each case description and facilitate comparison, we broke down and restructured the scenarios according to these themes. With the scenarios organized this way, defining characteristics were amplified to sharpen the contrasts between them. We then reassembled the storylines.

The revised scenarios were discussed during a focus-group meeting that we organized in Makanya in June 2007 with eight key informants from the first workshop (six farmers, one village chairman, and one extension officer). We made some smaller adjustments after this meeting, related to the relative importance of different variables in the different scenarios, and asked an artist to illustrate each scenario. By combining images and narratives, we were able to present a richer version of the final scenarios to the local community. This presentation 
Table 2. Ranking of driving forces. Access to new agricultural techniques was ranked as the most important driving force in the area, followed by health and local governance. The table also shows the participants' perception of how these factors will change in the coming decades. This is expressed as percentage of participants assessing the driving forces to become better/more, or worse/less, alternatively who don't know, in the future. $N=32$.

\begin{tabular}{|c|c|c|c|c|}
\hline Rank & Driving force & $\begin{array}{l}\text { Better/more } \\
\quad(\%)\end{array}$ & $\begin{array}{l}\text { Don't know } \\
\quad(\%)\end{array}$ & $\begin{array}{l}\text { Worse/less } \\
\quad(\%)\end{array}$ \\
\hline 1 & Access to new agricultural techniques (agromechanization, RWH) & 100 & 0 & 0 \\
\hline 2 & Health (HIV, nutrition) & 50 & 34 & 16 \\
\hline 3 & $\begin{array}{l}\text { Local governance (quality of leadership, measures against drug abuse, } \\
\text { environmental protection }\end{array}$ & 63 & 25 & 12 \\
\hline 4 & Access to higher education (secondary schools in the area) & 100 & 0 & 0 \\
\hline 5 & $\begin{array}{l}\text { Work ethics / family values (preserving local culture, and customs, } \\
\text { including traditional systems for environmental protection) }\end{array}$ & 38 & 50 & 12 \\
\hline 6 & National economy & 75 & 22 & 3 \\
\hline 7 & Infrastructure (transport and communication, market access, energy) & 88 & 9 & 3 \\
\hline 8 & Access to credit and savings opportunities & 84 & 13 & 3 \\
\hline 9 & $\begin{array}{l}\text { Approaches for collective action (common language, methods for } \\
\text { participatory work) }\end{array}$ & 69 & 31 & 0 \\
\hline 10 & Climate (rainfall amounts, variability) & 9 & 57 & 34 \\
\hline
\end{tabular}

was made at a meeting held in Makanya in December 2007, in which most of the participants from the first workshop took part. At this meeting, we also presented the local government and farmer field school network with a report of the scenarioplanning process in Makanya, that described the methodology as well as the results and that was intended as a support to take scenario work forward locally.

\section{RESULTS}

\section{Driving Forces for Change and Scenario Starting Points}

The scenario-planning process identified 43 drivers of change in the Makanya catchment, which were classified into 10 categories. Access to new agricultural technology was perceived as the most important factor driving development in the area, followed by health and local governance (Table 2). The scenario participants were quite optimistic, appraising most factors as becoming "better/more" in the coming two decades. This tendency toward optimism has been identified in scenario-planning processes elsewhere (cf. Wollenberg et al. 2000b). However, an important exception to the optimism was that workshop participants expected the future climate to worsen. The factors that were identified as both important and uncertain, and thus selected to form the scenario starting points, were "health," "local governance," "work ethics / family values," "national economy," and "climate" (see Table 3). To make sure that the starting points were not overly dominated by local driving forces, which participants were more familiar with, but which may not always be as important, we chose "national economy" over "approaches for collective action," although the latter was perceived as more uncertain. 
Table 3. Starting points for the scenarios. The conditions for the starting point of the storyline are defined as being better, undefined, or worse than the present (2006).

\begin{tabular}{lcccc}
\hline \hline & Scenario 1 & Scenario 2 & Scenario 3 & Scenario 4 \\
\hline Local governance & worse & worse & better & undefined \\
National economy & better & undefined & undefined & better \\
Climate & better & worse & worse & More variable \\
Health & undefined & undefined & better & better \\
Work ethics / family values & worse & undefined & better & worse \\
\hline
\end{tabular}

\section{The Scenarios}

The four scenarios, which all are based on the present-day situation in Makanya, but influenced by different combinations of changes in local governance, economy, climate, health, and values, are presented below. Table 4 compares the social, economic, and agricultural aspects of the scenarios. Figure 3 provides an impressionistic illustration of how the conditions in Makanya vary in the four scenarios, which is a cropped version of the illustrations that we used to communicate the scenarios to the local community. Central to the figure is one of Makanya's crossroads. We chose this focus both because it allowed us to show several different aspects of the livelihoods simultaneously, including infrastructure, trade, agriculture practices, and environment, and because the crossroad serves as a strong symbol of change.

\section{Agricultural advance}

In this scenario, a stable climate, a strong national economy, and investments by Tanzanian businessmen in food-processing industries drive a transition from subsistence-based to marketoriented production systems (see Appendix 2). Farming becomes mechanized and intensified, and new agricultural technologies spread fast from businessmen to farmers and among farmers. Although the catchment's economy and infrastructure grow quickly, social inequality increases, and the farmers become more vulnerable to crop-price fluctuations. The development improves the wellbeing of many farmers, but it also damages downstream water quality and reduces downstream water availability.

\section{Managing on the margins}

In this scenario, a drier climate makes farmingbased livelihoods difficult (see Appendix 2). In combination with institutional failure, this leads to societal fragmentation, as the weak leadership at local, regional, and national levels fails to deal with the situation. As a response to the declining productivity, a few entrepreneurs switch from farming to other income sources, and manage to improve their livelihoods. However, most of the population is "managing on the margins," forced to extractive use of farmland and other natural resources, and there is a vicious cycle of declining farm productivity and declining quality and quantity of the surrounding natural resource base that traps many farmers in poverty.

\section{Community cohesion}

In this scenario, people come together to address shared problems. Effective local leadership is complemented by the activities of NGOs, who enable village development projects (see Appendix 2 ). People still rely on small-scale farming, but incomes rise due to an increasing focus on highvalue organic production and new income opportunities such as ecotourism. Living standards gradually improve in the community, but livelihood security is still closely linked to rainfall. People 
Table 4. Scenario contrasts. The first column lists nine themes that were common for all scenarios. The table shows the main differences between the scenarios according to these themes.

\begin{tabular}{|c|c|c|c|c|}
\hline & Agricultural advance & Managing on the margins & Community cohesion & Industry imperial \\
\hline $\begin{array}{l}\text { Main income } \\
\text { sources }\end{array}$ & $\begin{array}{l}\text { Agriculture (cash crops } \\
\text { and bio-fuels), food } \\
\text { processing, petty trading }\end{array}$ & $\begin{array}{l}\text { Subsistence farming, } \\
\text { livestock keeping, logging, } \\
\text { charcoal making, } \\
\text { beekeeping, remittances }\end{array}$ & $\begin{array}{l}\text { Small-scale farming (also } \\
\text { organic), livestock, } \\
\text { ecotourism, handicrafts }\end{array}$ & $\begin{array}{l}\text { Mining, cement and tile } \\
\text { industries, office jobs, } \\
\text { transport, petty trading, } \\
\text { tourism }\end{array}$ \\
\hline Local economy & $\begin{array}{l}\text { Better economy, but } \\
\text { increased inequality }\end{array}$ & $\begin{array}{l}\text { No change for most, some } \\
\text { people worse off as harvests } \\
\text { fail, only better for a few }\end{array}$ & A bit better for most people & $\begin{array}{l}\text { Economic growth, but } \\
\text { capital leaves the area } \\
\text { Economic stratification }\end{array}$ \\
\hline $\begin{array}{l}\text { External change } \\
\text { agents } \\
\text { (The role of national } \\
\text { and local } \\
\text { governments vs. } \\
\text { other actors such as } \\
\text { NGOs and foreign } \\
\text { investors) }\end{array}$ & $\begin{array}{l}\text { Good investment } \\
\text { climate and subsidized } \\
\text { agricultural inputs make } \\
\text { Tanzanian businessmen } \\
\text { start food-processing } \\
\text { industries and bio-fuel } \\
\text { production in the area }\end{array}$ & $\begin{array}{l}\text { Local officials neglect their } \\
\text { duties } \\
\text { No efforts made by central } \\
\text { government to help local } \\
\text { communities cope with } \\
\text { drought or fight corruption } \\
\text { NGOs have a reactive rather } \\
\text { than proactive role, focusing } \\
\text { on, e.g., relief food }\end{array}$ & $\begin{array}{l}\text { Local government helps } \\
\text { initiate community groups, } \\
\text { supported by NGOs } \\
\text { Foreign-owned ecotourism } \\
\text { hotel run in cooperation with } \\
\text { community group }\end{array}$ & $\begin{array}{l}\text { Good economy has } \\
\text { connected Makanya to } \\
\text { the world, Chinese and } \\
\text { Kenyan industries } \\
\text { become important } \\
\text { Local government is } \\
\text { bypassed by investors, } \\
\text { over time it loses } \\
\text { influence }\end{array}$ \\
\hline $\begin{array}{l}\text { Source of } \\
\text { development } \\
\text { initiatives }\end{array}$ & $\begin{array}{l}\text { Individual, but } \\
\text { cooperatives emerge for } \\
\text { bio-fuel production }\end{array}$ & $\begin{array}{l}\text { Entrepreneurs leave farming } \\
\text { and start new businesses, } \\
\text { raising mixed feelings } \\
\text { among other villagers }\end{array}$ & $\begin{array}{l}\text { Community initiatives, small } \\
\text { self-help groups and credit } \\
\text { schemes }\end{array}$ & $\begin{array}{l}\text { New projects proposed } \\
\text { by companies rather than } \\
\text { local people or local } \\
\text { groups }\end{array}$ \\
\hline $\begin{array}{l}\text { Social cohesion / } \\
\text { inequality }\end{array}$ & $\begin{array}{l}\text { Growing inequality, } \\
\text { everyone cannot keep up } \\
\text { with the rapid } \\
\text { development, } \\
\text { aggravated by } \\
\text { competition over land }\end{array}$ & $\begin{array}{l}\text { Low community spirit / } \\
\text { working morale } \\
\text { Fewer children from poor } \\
\text { families in school leads to } \\
\text { increasing inequality }\end{array}$ & $\begin{array}{l}\text { Good community spirit, } \\
\text { people work together during } \\
\text { crisis years, but group work } \\
\text { benefits some more than } \\
\text { others }\end{array}$ & $\begin{array}{l}\text { There is a clear difference } \\
\text { between those who can } \\
\text { influence their work } \\
\text { situation and those who } \\
\text { work in mines and } \\
\text { factories }\end{array}$ \\
\hline Values & $\begin{array}{l}\text { Traditional values are } \\
\text { nurtured, but } \\
\text { modernization occurs } \\
\text { anyway }\end{array}$ & $\begin{array}{l}\text { People strongly object to the } \\
\text { stratification that occurs }\end{array}$ & $\begin{array}{l}\text { Traditional family values } \\
\text { important, but people are } \\
\text { open to modernization as long } \\
\text { as it is equitable }\end{array}$ & $\begin{array}{l}\text { Young people adopt a } \\
\text { more modern life style, } \\
\text { elderly people lose } \\
\text { authority }\end{array}$ \\
\hline Infra-structure & $\begin{array}{l}\text { Much better roads and } \\
\text { housing }\end{array}$ & Only slowly improving & $\begin{array}{l}\text { Local road is improving due } \\
\text { to ecotourism project }\end{array}$ & $\begin{array}{l}\text { Much better roads, } \\
\text { computers and phones } \\
\text { common, improved but } \\
\text { stratified housing }\end{array}$ \\
\hline Population & $\begin{array}{l}\text { Population growth } \\
\text { (some in-migration, less } \\
\text { out-migration), labor } \\
\text { available }\end{array}$ & $\begin{array}{l}\text { Out-migration for irrigated } \\
\text { agriculture }->\text { declining } \\
\text { population and lack of labor }\end{array}$ & $\begin{array}{l}\text { Slowly growing, but young } \\
\text { people still move to urban } \\
\text { areas if they can }\end{array}$ & $\begin{array}{l}\text { Increasing movements, } \\
\text { both in and out- } \\
\text { migration, fewer people } \\
\text { per household }\end{array}$ \\
\hline $\begin{array}{l}\text { Agroecological } \\
\text { conditions } \\
\text { (Extent of cultivated } \\
\text { areas, agricultural } \\
\text { production systems, } \\
\text { environmental } \\
\text { health) }\end{array}$ & $\begin{array}{l}\text { The cultivated area } \\
\text { increases substantially } \\
\text { Mechanized cash-crop } \\
\text { production, increasing } \\
\text { use of inputs } \\
\text { Homogenization of land } \\
\text { use, pesticide residues in } \\
\text { water, decreasing forest } \\
\text { and bush cover }\end{array}$ & $\begin{array}{l}\text { The cultivated area } \\
\text { decreases } \\
\text { Small-scale subsistence } \\
\text { farming relying on } \\
\text { traditional practices } \\
\text { Depleting farming methods, } \\
\text { and problems with land } \\
\text { degradation following } \\
\text { overextraction of ecosystem } \\
\text { services such as fodder, } \\
\text { timber, and charcoal }\end{array}$ & $\begin{array}{l}\text { The cultivated area increases } \\
\text { Subsistence farming with an } \\
\text { increasing cash-crop } \\
\text { component due to new small- } \\
\text { scale technologies } \\
\text { Organic farming movement } \\
\text { and less-depleting practices } \\
\text { Community forest reserve }\end{array}$ & $\begin{array}{l}\text { The cultivated area } \\
\text { decreases, with the } \\
\text { exception of the } \\
\text { highlands where irrigated } \\
\text { vegetable production still } \\
\text { takes place } \\
\text { Less environmental } \\
\text { impact from farming, but } \\
\text { problems associated with } \\
\text { industrialization } \\
\text { National Park established } \\
\text { in the highlands }\end{array}$ \\
\hline
\end{tabular}


Fig. 3. Four scenarios for Makanya's future. The figure gives an impressionistic illustration of how the conditions in Makanya vary in the four scenarios. Central to the figure is one of Makanya's crossroads, which is a strong symbol of change. "Agricultural advance" describes a future dominated by a rapid market-oriented agricultural development. In "Managing on the margins," the dry climate makes farming-based livelihoods difficult and people have to struggle to provide for their families.

"Community cohesion" centers on collective action and small-scale improvements of current farming systems. "Industry imperial" describes a future where smallholder farming loses importance as people start working in industries and factories, and where the traditional lifestyle increasingly becomes abandoned. Illustration: C. Bollner/Azote.se
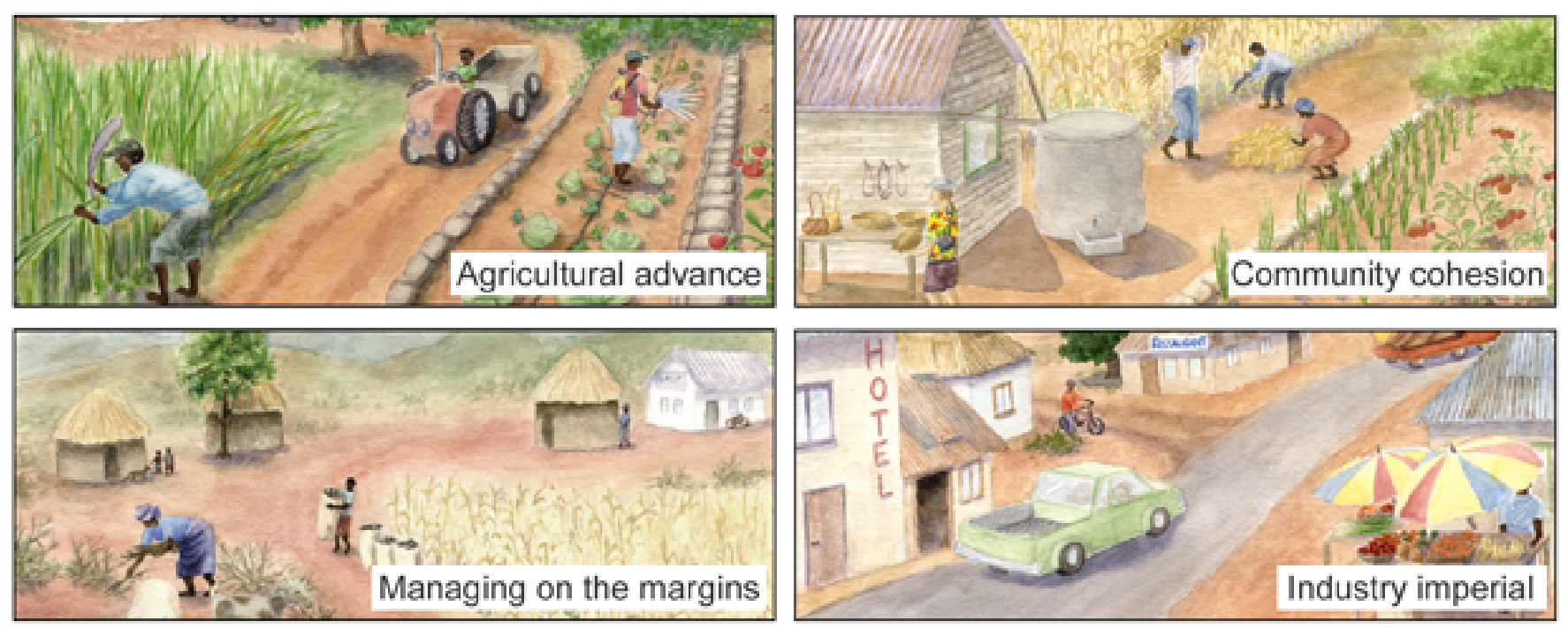

work together to reduce the impact of drought, for example by building communal grain storage silos. The agroecological productivity in the catchment is sustained through improved farmland and ecosystem management, but overall the development is considerably slower than in "Agricultural advance."

\section{Industry imperial}

In this scenario, the national economy is growing, and national as well as foreign investors are attracted to Makanya to establish new enterprises (see Appendix 2). In most of the catchment, agriculture loses importance as people engage in mining or start working in factories. Farming persists in the highlands, where irrigated vegetable production remains common. Some of the villages in the catchment grow together, forming smaller towns, and people adopt a more urbanized lifestyle. The development is rapid and living standards improve for many, but the society also becomes more unequal. A substantial part of the money generated in the catchment leaves the area. New environmental problems are emerging, especially related to the mining industry, which pollutes air and water.

Although the four scenarios display fundamental differences (Table 4), there were also a number of recurring themes that dominated the discussions during the scenario workshop, and that appeared in all scenarios regardless of the starting point. Among these is the strong identity as farmers and livestock keepers held by the people in the catchment (the loss of which in the industrialization scenario was seen as problematic by many of the participants), and the preference for collective action over individual initiatives for development. The latter fits well with the important roles played by central government and NGOs in most of the scenarios. It was, for 
example, clear that many participants were uncomfortable with both "Agricultural advance" and "Managing on the margins" specifically because individual entrepreneurship played a more important role in these scenarios than collective action did. Despite these feelings, it was the general opinion among the workshop participants that this development was quite plausible. Finally, there also seemed to be a substantial worry about loss of local customs and changing ideals among the younger generations.

\section{DISCUSSION}

\section{Increasing the Robustness of Agricultural Investments}

In the sections below, we analyze a range of technological, economical, social, and environmental factors that could influence the success of investments in small-scale water system innovations across the scenarios (see Table 5). The analysis suggests that there are numerous ways that policies could be designed for increased robustness to meet an uncertain future.

\section{Choosing Water System Technologies}

The kind of water system technology that would be most efficient in promoting agricultural development varies across the scenarios, based primarily on the ability of farmers to organize themselves, the level of food security, and the access to markets. One factor that stands out is the capacity for collective action needed for successful management in, for example, small-scale irrigation systems (Ostrom 1990, Meinzen-Dick 2007). Technology that depends only on the work of individual farmers or households, such as conservation tillage or household-scale rainwater harvesting, would likely work well in "Agricultural advance" and "Managing on the margins." However, technologies that require communal efforts to function effectively, such as many small-scale irrigation systems, would likely not, due to the lack of local leadership and collaborative spirit. A project promoting a technology that depends on communal efforts would have to make large efforts to build social capital (cf. Pretty and Ward 2001) to make it work under such conditions. The relative usefulness of technologies targeting staple-crop vs. cash-crop production also varies across the scenarios. A focus on cereal production seems necessary in scenarios where people are vulnerable to food shortage, such as "Managing on the margins" and to lesser extent "Community cohesion." A focus on cash crops, such as vegetables, flowers, and bio-fuels, seems more productive in situations when food security is higher and farmers have access to markets, such as in "Agricultural advance," "Community cohesion," and "Industry imperial" (for the highland vegetable growers).

The analysis shows that there is no single agricultural water management technology that will perform well across all scenarios. This suggests that, as a complement to investments in specific technologies, it would be useful with more agricultural intervention programs that promote learning, experimentation, and innovation among farmers (Röing and Wagemakers 1998), as this would lead to benefits in any of the scenarios. For such programs to be successful, they would have to (a) provide incentives for farmer innovation (most likely plausible at a smaller scale), (b) strengthen the capacity to monitor and evaluate outcomes, and (c) create an environment that tolerates experimental failures. The last point is particularly important in areas that suffer from low food security. More research would be required to design an approach specifically suitable in Makanya, but there are many general types of programs and interventions that could facilitate adaptive experimentation. Microcredit schemes can be used to promote low-risk investment, and seem especially promising for poverty reduction when combined with various types of insurance (Zeller and Sharma 2000). The creation of knowledgeexchange forums, such as farmer field schools and farmer learning groups, can help farmers monitor and evaluate new technology, and spread new ideas (Hagmann and Chuma 2002). Local, regional, or national crop-insurance systems can be designed to provide a safety net that makes experimentation and innovation possible.

\section{Choosing Collaborative Partners}

The scenarios also show that there are several ways in which Makanya may be linked to regional, national, and global economic systems in the future. Agricultural development interventions, such as action research projects for example, need to understand the nature of these connections in order to be successful as they will influence the spread and adoption of new agricultural technology. Suitable collaborative partners will vary among the 
Table 5. Implications for small-scale water system investments in the different scenarios. The table shows some technological, environmental, economic, and social issues that are relevant for successful investments in small-scale water system technologies in the different scenarios.

\begin{tabular}{|c|c|c|c|c|}
\hline & Agricultural advance & Managing on the margins & Community cohesion & Industry imperial \\
\hline Technology & $\begin{array}{l}\text { Water system } \\
\text { innovations very } \\
\text { important } \\
\text { Individually managed } \\
\text { small-scale technologies } \\
\text { independent of the need } \\
\text { for increased community } \\
\text { involvement } \\
\text { Investors to decide to } \\
\text { who to target: market- } \\
\text { oriented farmers or more } \\
\text { marginalized groups. } \\
\text { This affects staple or } \\
\text { cash crop focus, and } \\
\text { what kind of } \\
\text { technologies are suitable. }\end{array}$ & $\begin{array}{l}\text { Focus on technologies with } \\
\text { capacity to bridge dry spells } \\
\text { and stabilize cereal } \\
\text { production } \\
\text { Focus on individual solutions } \\
\text { Water system innovations for } \\
\text { livestock } \\
\text { Risk for maladaptation due to } \\
\text { climate change }\end{array}$ & $\begin{array}{l}\text { Water system innovations } \\
\text { are important in both staple- } \\
\text { and cash-crop production } \\
\text { Coordinate with organic } \\
\text { farming practices with } \\
\text { potential to develop "niche } \\
\text { market" for organic } \\
\text { products } \\
\text { Can include broader range } \\
\text { of technologies including } \\
\text { individual as well as } \\
\text { community solutions }\end{array}$ & $\begin{array}{l}\text { Water system innovations } \\
\text { have limited relevance, } \\
\text { except for in the highlands' } \\
\text { vegetable production } \\
\text { systems } \\
\text { Larger-scale irrigation that } \\
\text { provides employment rather } \\
\text { than subsistence might } \\
\text { become relevant }\end{array}$ \\
\hline Environment & $\begin{array}{l}\text { Upstream-downstream } \\
\text { implications from } \\
\text { increasing water } \\
\text { withdrawal and nutrient } \\
\text { or pesticide leakage } \\
\text { Expansion of cultivated } \\
\text { areas-reserves and } \\
\text { protected areas might be } \\
\text { needed } \\
\text { Potential for PES and } \\
\text { water credit schemes }\end{array}$ & $\begin{array}{l}\text { Projects need to include a } \\
\text { land-restoration component } \\
\text { to deal with land degradation } \\
\text { and target the feedback } \\
\text { between declining on-farm } \\
\text { productivity and declining } \\
\text { productivity of the } \\
\text { surrounding resource base }\end{array}$ & $\begin{array}{l}\text { Sustained capacity for } \\
\text { agroecological productivity } \\
\text { Potential for sustainable } \\
\text { intensification of } \\
\text { agriculture, where both food } \\
\text { and other ecosystem } \\
\text { services are generated }\end{array}$ & $\begin{array}{l}\text { Opportunities for } \\
\text { "European" type of } \\
\text { landscape protection, where } \\
\text { traditional production system } \\
\text { and small-scale technologies } \\
\text { are valued and protected }\end{array}$ \\
\hline Economy & $\begin{array}{l}\text { Potential to link projects } \\
\text { (if business focus) with } \\
\text { marketing and business } \\
\text { skills } \\
\text { Potential development of } \\
\text { markets for ecosystem } \\
\text { services } \\
\text { Potential to work with } \\
\text { food-processing } \\
\text { enterprises? }\end{array}$ & $\begin{array}{l}\text { Limited economic } \\
\text { opportunities } \\
\text { Focus on investments with } \\
\text { low initial costs to avoid } \\
\text { maladaptations }\end{array}$ & $\begin{array}{l}\text { Economic potential of } \\
\text { tourist industry for organic } \\
\text { produce and niche products } \\
\text { Marketing skills need to be } \\
\text { improved }\end{array}$ & $\begin{array}{l}\text { Economic potential for } \\
\text { highland vegetable growers } \\
\text { Marketing skills need to be } \\
\text { improved }\end{array}$ \\
\hline Social factors & $\begin{array}{l}\text { Individual focus needed } \\
\text { because it would be } \\
\text { difficult to force } \\
\text { community initiatives } \\
\text { Potential for specifically } \\
\text { targeting entrepreneurs } \\
\text { and other key individuals }\end{array}$ & $\begin{array}{l}\text { Focus on building social } \\
\text { capital OR finding individual } \\
\text { entrepreneurs }\end{array}$ & $\begin{array}{l}\text { Potential to use local groups } \\
\text { and NGOs to enter the area } \\
\text { and for disseminating } \\
\text { knowledge (e.g., already } \\
\text { existing farmer learning } \\
\text { groups) and for long-term } \\
\text { impact }\end{array}$ & $\begin{array}{l}\text { Target specific groups that } \\
\text { will farm in the future (such } \\
\text { as retired people in the } \\
\text { highlands engaged in small- } \\
\text { scale vegetable production) }\end{array}$ \\
\hline
\end{tabular}


scenarios. In "Agricultural advance" and "Industry imperial," local businessmen constitute an important group. In "Community cohesion," NGOs are central, along with the local tourism industry. Local farmers with entrepreneurial skills and, to a lesser extent, also NGOs are key groups in "Managing on the margins."

The most relevant group to work with will also vary depending on the goal of the intervention. A central question is whether the purpose is to seize an opportunity for economic growth that perhaps is only accessible for a smaller subsection of the population, or if it is to minimize the risk of food insecurity for poorer sectors of the population. In "Agricultural advance," for example, a project dealing with small-scale water system technologies could either target farmers who produce cash crops to boost their production and improve their market integration, hoping that this would have positive spillover effects on the community in terms of a growing economy, or it could target the farmers who are not keeping up with the agricultural development, and who are becoming increasingly marginalized to reduce their vulnerability. In the first case, local businessmen and cash-crop growers are central for success, whereas in the latter case, other groups are more important. The analysis suggests that there is not one ideal group for research and development projects to work with, and highlights the importance of being aware of different stakeholder groups in a local community and identifying a diverse set of potential partners. Such an approach would trade off robustness against the amount of investment that can be made in one group, but we expect that involving people who bridge multiple groups can reduce this trade-off.

\section{Adopting a Systemic Approach}

A comparison of the scenarios shows that they are vulnerable to environmental problems produced as unintended consequences of the development. Analyzing the systemic consequences of development activities could help in designing interventions that reduce, mitigate, or facilitate adaptation to unwanted environmental change. For example, in "Agriculture advance," the agricultural development leads to undesirable downstream consequences, which include the loss of important freshwater ecosystem services. Proactively dealing with these problems requires that projects concerned with water system technologies adopt an upstreamdownstream perspective as a basis for the proposed interventions. Such efforts could include strengthening collaborations and institutional arrangements between farmers living upstream and downstream. In other places, this type of effort has included payments for ecosystem services or for water credits (see, e.g., Pagiola et al. 2005, International Soil Reference and Information Centre (ISRIC) 2007). The environmental issues that arise in "Managing on the margins" are due to land degradation, both on farm as a consequence of soil erosion and surface crusting, and in the surrounding landscape due to farmers' strong reliance on non-agricultural ecosystem services, such as fodder for livestock, timber, and charcoal when harvests fail. This highlights the importance of treating farmers' livelihood systems as entities, and developing projects that target the interactions between on-farm productivity and productivity of the surrounding resource base (see Enfors and Gordon 2007).

"Managing on the margins" also provides another example that illustrates why a systems perspective is needed. The land degradation, changing climate, and general lack of development in the scenario means that a farmer investing in, e.g., a rainwater harvesting system for vegetable production is running a large risk of losing the investment, potentially leaving him or her worse off than before, unless the local investment is backed up by necessary investments at other levels, e.g., in failsafe arrangements, infrastructure, and markets. Thus, to reduce the risk for maladaptation, relevant investments have to be coordinated across scales (cf. Barrett and Swallow 2006). This requires an understanding of interactions between different social-ecological system levels (Enfors and Gordon2008).

\section{How Can We Tell Which World Is Emerging?}

The scenarios are not predictions of the future, but represent an attempt to scan across a range of future possibilities. It is unlikely that Makanya will follow the exact path of either scenario, but Makanya 2030 will likely exhibit aspects of all four scenarios. Two key issues emerge; how can we know what kind of world that is developing, and how do we promote desirable trajectories of development? The scenarios can help identify indicators of the pathway upon which a region is developing. For example, a major difference between "Managing on the margins" and "Community cohesion," and to some extent "Agricultural advance," is the level of local 
ecological resilience. The capacity of the ecosystem to provide support for livelihoods during droughts and dry spells could be one biophysical variable that indicates in which direction the development is heading. Two social factors at a regional scale that could be monitored are trends in investment and outmigration. Large-scale external investment would suggest that the region is heading toward an "Industry imperial"-like situation. Low outmigration, combined with collective action, would indicate that the region is heading toward a scenario like "Community cohesion." These are some of the variables that can be monitored to better guide investments in small-scale agriculture, to where they will give best result. In addition, making investments that also attempt to shape internal and external drivers of change could be a way to move communities like Makanya away from undesired development trajectories and toward desired ones.

\section{Lessons Learned from the Makanya Scenario Experience}

Although the participatory scenario-planning process took more time and effort than a regular system analysis would have done, it allowed us to better explore key uncertainties in the region and identify what kind of development efforts would be useful under different future conditions that are relevant in the local context. Developing participatory scenarios also proved to be a useful tool to rapidly assess some of the major hopes, fears, and thoughts about the future among people in the local community. Such an overview is useful in any project, especially in a start-up phase. In this particular case, where the objective was to assess the relevance of investments in agricultural technologies that are intended for small-scale farmers, this perspective was essential because the farmers' risk calculations and expectations of the future will influence whether or not, and under what conditions, they will adopt small-scale water system technologies.

Furthermore, there seems to be a risk that development and applied research projects become trapped in a vision that describes how their proposed interventions will ideally unfold over time. Scenario planning may help overcome such biases (Wollenberg et al. 2000b) as it facilitates an understanding of how the project could develop in different kind of futures and because it improves the understanding of events and processes that either may challenge the project or provide opportunities for it (cf. Bennett and Zurek 2006). Developing alternative scenarios, parallel to the project vision, forces you to think about factors that might alter the expected development path. Moreover it forces you to consider a number of interacting driving forces simultaneously, in a way that embraces the complexity of reality, likely improving the chances for success.

Although it is a promising tool, a number of difficulties also presented themselves during the scenario-planning process in Makanya. For example, when creating scenarios at such a local level, there is an evident risk for bias toward locallevel driving forces and underestimation of external forces shaping the region. This is especially the case when then the scenarios are developed by people with limited formal education and limited experience of other places, and who might not be very used to thinking about hypothetical issues. Although this can be balanced to a certain degree by basing the scenarios on official statistics, it is virtually impossible to know whether another set of scenarios actually would have been more relevant for the system. It has been suggested that multi-scale scenarios, where storylines are developed at several organizational levels and then linked together, can be used to reduce this problem, but there are still very few examples of scenario-planning processes that have successfully integrated multiple scales (Biggs et al. 2007, Kok et al. 2007).

Finally, scenario planning can be a tool for local empowerment. Identifying opportunities and threats that might present themselves in the future could help a community to steer its development in a more desirable direction and thus help local people to take more control over their future (Peterson 2007). However, this is a long and challenging process, and although the scenario-planning process contributed to our understanding of the fit of agricultural development into a local context, the extent to which the scenario process will contribute to local empowerment in Makanya is yet unclear.

\section{CONCLUSIONS}

Investments in small-scale water system technologies appear to be valuable in all scenarios, but the most relevant technologies vary between them. A way to increase the robustness of this type of investments is to build capacity among farmers for innovation 
and learning through experimentation, as this will generate benefits across a range of possible futures. The analysis shows that there is not one ideal type of collaborative partner for research and development projects working with small-scale agricultural technology, highlighting the importance of identifying a diverse set of potential collaborators. When choosing between them, it is important to be clear about the goals of the project, referring particularly to whether these goals relate to seizing opportunities or avoiding risks. Furthermore, having a systems approach to these investments is important across all scenarios, especially for dealing with unintended environmental consequences arising from the agricultural development. The systems perspective implies different things in the different scenarios, ranging from consideration of upstream-downstream issues, understanding of the dynamic interaction between farming systems and the larger agroecosystem, and coordination of relevant investments across social-ecological system levels. We conclude that although the method presents some challenges, participatory scenario planning is a useful tool for integrating research and development projects in the larger context because it increases the understanding of events and processes that may either challenge the project or provide opportunities for it.

Responses to this article can be read online at: http://www.ecologyandsociety.org/voll3/iss2/art42/ responses/

\section{Acknowledgments:}

We are grateful to the people of the Makanya catchment who participated in the scenarioplanning process. We are also thankful to Elena Bennett and Ciara Raudshepp-Hearne, and to two anonymous reviewers, for comments on earlier drafts of this paper. The work reported here was undertaken as part of the Smallholder System Innovations in Integrated Watershed Management (SSI) Program supported by the Netherlands Foundation for the Advancement of Tropical Research (WOTRO), the Swedish International Development Cooperation Agency (Sida), the Netherlands Directorate-General of Development Cooperation (DGIS), the International Water Management Institute (IWMI), UNESCO-IHE Institute for Water Education, Sokoine University of Agriculture (SUA), Tanzania, University of KwaZulu Natal (UKZN), South Africa, and Stockholm University (SU), Sweden. Gordon's work was also funded by FORMAS, while Peterson was supported by the Canada Research Chairs program. The SoilWater Management Research group (SWMRG) of SUA assisted with the implementation of field research.

\section{LITERATURE CITED}

Baker, J. P., D. W. Hulse, S. V. Gregory, D. White, J. van Sickle, P. A. Berger, D. Dole, and N. H. Schumaker. 2004. Alternative futures for the Willamette River Basin, Oregon. Ecological Applications 14(2):313-324.

Barrett, C. B., and B. M. Swallow. 2006. Fractal poverty traps. World Development 34(1):1-15.

Bennett, E., and M. Zurek, editors. 2006. Field guide to the future: four ways for communities to think ahead. Center for Interational Forestry Research (CIFOR), Alternatives to Slash and Burn (ASB), World Agroforestry Center, Nairobi, Kenya.

Bhatt, Y., D. Bossio, E. Enfors, L. Gordon, V. Kongo, J. Kosgei, H. Makurira, K. Masuki, M. Mul, and S. Tumbo. 2006. Smallholder system innovations in integrated watershed management (SSI): strategies of water for food and environmental security in drought-prone tropical and sub-tropical agro-ecosystems. International Water Management Institute, Colombo, Sri Lanka. [online] URL: http://www.iwmi.cgiar.org/Publications/ Working Papers/index.aspx.

Biggs, R., C. Raudsepp-Hearne, C. AtkinsonPalombo, E. Bohensky, E. Boyd, G. Cundill, H. Fox, S. Ingram, K. Kok, S. Spehar, M. Tengo, D. Timmer, and M. Zurek. 2007. Linking futures across scales: a dialog on multiscale scenarios. Ecology and Society 12(1): 17. [online] URL: http: //www.ecologyandsociety.org/vol12/iss1/art17/.

Boko, M., I. Niang, A. Nyong, C. Vogel, A. Githeko, M. Medany, B. Osman-Elasha, R. Tabo, and P. Yanda. 2007. Africa. Pages 433-467 in M. L. Parry, O. F. Canziani, J. P. Palutikof, P. J. van der Linden, and C. E. Hanson, editors. Climate change 2007: impacts, adaptation and vulnerability. 
Contribution of Working Group II to the Fourth Assessment Report of the Intergovernmental Panel on Climate Change. Cambridge University Press, Cambridge, UK.

Bryceson, D. F. 1996. Deagrarianization and rural employment in sub-Saharan Africa: a sectoral perspective. World Development 24(1):97-111.

Bryceson, D. F. 2002. The scramble in Africa: reorienting rural livelihoods. World Development 30(5):725-739.

Christensen, J. H., B. Hewitson, A. Busuioc, A. Chen, X. Gao, I. Held, R. Jones, R. K. Kolli, W.T. Kwon, R. Laprise, V. Magana Rueda, L. Mearns, C. G. Menédez, J. Raisanen, A. Rinke, A. Sarr, and P. Whetton. 2007. Regional climate projections. Pages 847-940 in S. Solomon, D. Qin, M. Manning, Z. Chen, M. Marquis, K. B. Averyt, M. Tignor, and M. H.L., editors. Climate change 2007: the physical science basis. Contribution of Working Group I to the Fourth Assessment Report of the Intergovernmental Panel on Climate Change. Cambridge University Press, Cambridge, UK and New York, New York, USA.

Comprehensive Assessment of Water Management in Agriculture. 2007. Water for food, water for life: a comprehensive assessment of water management in agriculture. Earthscan, London, UK.

Diao, X., P. Hazell, D. Resnick, and J. Thurlow. 2007. The role of agriculture in development: implications for Sub-Saharan Africa. Research report 153. International Food Policy Research Institute (IFPRI), Washington, D.C., USA. [online] URL: http://www.ifpri.org/pubs/ABSTRACT/rr153. asp.

Easterling, W. E., P. K. Aggarwal, P. Batima, K. M. Brander, L. Erda, S. M. Howden, A. Kirilenko, J. Morton, J.-F. Soussana, J. Schmidhuber, and F. N. Tubiello. 2007. Food, fibre and forest products. Pages 273-313 in M. L. Parry, O. F. Canziani, J. P. Palutikof, P. J. van der Linden, and C. E. Hanson, editors. Climate change 2007: impacts, adaptation and vulnerability. Contribution of Working Group II to the Fourth Assessment Report of the Intergovernmental Panel on Climate Change. Cambridge University Press, Cambridge, UK.

Ellis, F. 1998. Household strategies and rural livelihood diversification. Journal of Development
Studies 35(1):1-38.

Enfors, E., and L. Gordon. 2007. Analyzing resilience in dryland agro-ecosystems: a case study of the Makanya catchment in Tanzania over the past 50 years. Land Degradation and Development 18:680-696.

Enfors, E. I., and L. J. Gordon. 2008. Strategies to deal with drought among smallholder farmers in semiarid Tanzania: a study from the Makanya catchment of climate related poverty traps and small-scale supplemental irrigation. Global Environmental Change: in press.

Falkenmark, M., and J. Rockström. 2004. Balancing water for humans and nature: the new approach in ecohydrology. Earthscan Publications Ltd., London, UK.

Food and Agriculture Organization (FAO). 2008. Agro-MAPS: global spatial database of agricultural land-use statistics. [online] URL: http://www.fao.o rg/landandwater/agll/agromaps/interactive/page.jspx

FAO/New Partnership for Africa's Development (NEPAD). 2002. Comprehensive Africa Agriculture Development Programme (CAADP). FAO, Rome, Italy.

Fox, P., and J. Rockström. 2003. Supplemental irrigation for dry-spell mitigation of rainfed agriculture in the Sahel. Agricultural Water Management 61(1):29-50.

Gallopin, G., A. Hammond, P. D. Raskin, and R. J.Swart. 1997. Branch points: global scenarios and human choice. Stockholm Environment Institute, Stockholm, Sweden.

Gordon, L. J., G. D. Peterson, and E. M. Bennett. 2008. Agricultural modifications of hydrological flows create ecological surprises. Trends in Ecology and Evolution 23(4):211-219.

Hagmann, J., and E. Chuma. 2002. Enhancing the adaptive capacity of the resource users in natural resource management. Agricultural Systems $\mathbf{7 3}$ (1):23-39.

International Soil Reference and Information Centre (ISRIC). 2007. Green water credits. World Soil Information Policy Brief. ISRIC, Wageningen, The Netherlands. [online] URL: http://www.isric.org/ 
UK/About+ISRIC/Projects/Current+Projects/Green+ Water+Credits.htm

Kahinda, J. M. M., J. Rockström,A. E. Taigbenu, and J. Dimes. 2007. Rainwater harvesting to enhance water productivity of rainfed agriculture in the semiarid Zimbabwe. Physics and Chemistry of the Earth 32(15-18):1068-1073.

Kok, K., R. Biggs, and M. Zurek. 2007. Methods for developing multiscale participatory scenarios: insights from southern Africa and Europe. Ecology and Society 12(1): 8. [online] URL: http://www.eco logyandsociety.org/vol12/iss1/art8/.

Liu, F. M., Y. Q. Wu, H. L. Xiao, and Q. Z. Gao. 2005. Rainwater-harvesting agriculture and wateruse efficiency in semiarid regions in Gansu province, China. Outlook on Agriculture 34(3):159165.

Makurira, H., H. H. G. Savenije, S. Uhlenbrook, J. Rockström, and A. Senzanje. 2007. Towards a better understanding of water partitioning processes for improved smallholder rainfed agricultural systems: a case study of Makanya catchment, Tanzania. Physics and Chemistry of the Earth 32 (15-18):1082-1089.

Meinzen-Dick, R. 2007. Beyond panaceas in water institutions. Proceeding of the National Academy of Sciences 104(39):15200-15205.

Millennium Ecosystem Assessment. 2005. Ecosystems and human wellbeing: desertification synthesis. World Resources Institute, Washington D.C., USA. [online] URL: http://www.millennium assessment.org/en/Synthesis.aspx.

Mortimore, M. 2005. Dryland development: success stories from West Africa. Environment 47 (1):8-21.

Ostrom, E. 1990. Governing the commons: the evolution of institutions for collective action. Cambridge University Press, New York, New York, USA

Pagiola, S., A. Arcenas, and G. Platais. 2005. Can payments for environmental services help reduce poverty? An exploration of the issues and the evidence to date from Latin America World Development 33(2):237-253.

Peacock, A., C. Ward, and G. Gamarelli, compilers. 2007. Investment in agricultural water for poverty reduction and economic growth in SubSaharan Africa: a collaborative programme. Synthesis report. African Development Bank (AfDB), Food and Agriculture Organization (FAO), International Fund for Agricultural Development (IFAD), International Water Management Institute (IWMI), and World Bank [online] URL: http://siter esources.worldbank.org/RPDLPROGRAM/

Resources/459596-1170984095733/synthesisreport. pdf.

Peterson, G. D. 2007. Using scenario planning to enable an adaptive co-management process in the Northern Highlands Lake District of Wisconsin. Pages 289-307 in F. Berkes, D. Armitage, and N. Doubleday, editors. Adaptive co-management: collaboration, learning, and multi-level governance. UBC Press, Vancouver, British Columbia, Canada.

Peterson, G. D., G. S. Cumming, and S. R. Carpenter. 2003. Scenario planning: a tool for conservation in an uncertain world. Conservation Biology 17(2):358-366.

Pretty, J., and H. Ward. 2001. Social capital and the environment. World Development 29( 2):209227.

Raskin, P. D. 2005. Global scenarios: background review for the Millennium Ecosystem Assessment. Ecosystems 8(2):133-142.

Reynolds, J. F., D. M. S. Smith, E. F. Lambin, B. L. Turner, M. Mortimore, S. P. J. Batterbury, T. E. Downing, H. Dowlatabadi, R. J. Fernandez, J. E. Herrick, E. Huber-Sannwald, H. Jiang, R. Leemans, T. Lynam, F. T. Maestre, M. Ayarza, and B. Walker. 2007. Global desertification: building a science for dryland development. Science 316(5826):847-851.

Rockström, J., C. Folke, L. Gordon, N. Hatibu, G. Jewitt, F. P. de Vries, F. Rwehumbiza, H. Sally, H. Savenije, and R. Schulze. 2004. A watershed approach to upgrade rainfed agriculture in water scarce regions through Water System Innovations: an integrated research initiative on water for food and rural livelihoods in balance with ecosystem functions. Physics and Chemistry of the Earth 29 (15-18):1109-1118.

Röing, N. G., and M. A. E. Wagemakers, editors. 1998. Facilitating sustainable agriculture: participatory learning and adaptive management in times of 
environmental uncertainty. Cambridge University Press, Cambridge, UK and New York, New York, USA.

Same District Council. 2006. District Profile 2006: Same District. Same, Tanzania.

Santelmann, M. V., D. White, K. Freemark, J. I. Nassauer, J. M. Eilers, K. B. Vache, B. J. Danielson, R. C. Corry, M. E. Clark, S. Polasky, R. M. Cruse, J. Sifneos, H. Rustigian, C. Coiner, J. Wu, and D. Debinski. 2004. Assessing alternative futures for agriculture in Iowa, USA. Landscape Ecology 19(4):357-374.

Shah, T., M. Alam, M. D. Kumar, R. K. Nagar, and M. Singh. 2000. Pedaling out of poverty: social impact of a manual irrigation technology in South Asia. International Water Management Institute (IWMI), Colombo, Sri Lanka.

Steinitz, C., H. Arias, S. Bassett, M. Flaxman, T. Goode, T. Maddock, III, D. Mouat, R. Peiser, and A. Shearer. 2003. Alternative futures for changing landscapes: the Upper San Pedro River Basin in Arizona and Sonora. Island Press, Washington D. C., USA.

The United Republic of Tanzania. 2001. Agricultural sector development strategy. Food and Agricultural Sectors Working Group, Dar es Salaam, Tanzania.

The United Republic of Tanzania. 2002. 2002 Population and housing census. National Bureau of Statistics, Dar es Salaam, Tanzania.

The United Republic of Tanzania. 2005a. Poverty and human development report. The Research and Analysis Working Group, Dar es Salaam, Tanzania.

The United Republic of Tanzania. 2005b. The Agricultural Sample Census Survey 2002/03. National Bureau of Statistics, Dar es Salaam, Tanzania.

The United Republic of Tanzania. 2006. Mkukuta status report 2006: progress towards the goals for growth, well-being and governance in Tanzania. Ministry of Planning, Economy and Empowerment, Dar es Salaam, Tanzania.

Tress, B., and G. Tress. 2003. Scenario visualisation for participatory landscape planning
- a study from Denmark. Landscape and Urban Planning 64(3):161-178.

United Nations Development Programme (UNDP). 2006. Human development report 2006. Beyond scarcity: power, poverty and the global water crisis. Palgrave Macmillan, New York, New York, USA. [online] URL: http://hdr.undp.org/en/r eports/global/hdr2006/.

UNDP. 2007. Human development report 2007/2008: Fighting climate change: human solidarity in a divided world. Palgrave Macmillan, New York, New York, USA. [online] URL: http:// hdr.undp.org/en/reports/global/hdr2007-2008/.

United Nations department of Economic and Social Affairs (UNESA). 2008. World urbanization prospects: the 2007 revision population database. [online] URL: http://esa.un.org/unup

van der Heijden, K. 1996. Scenarios: the art of strategic conversation. Wiley, New York, New York, USA.

van Notten, P. W. F., J. Rotmans, M. B. A. van Asselt, and D. S. Rothman. 2003. An updated scenario typology. Futures 35(5):423-443.

Wack, P. 1985. Scenarios: uncharted waters ahead. Harvard Business Review 63:72--89.

World Resources Institute (WRI). 2005. World resources 2005: the wealth of the poor-managing ecosystems to fight poverty. WRI, Washington D. C., USA. [online] URL: http://archive.wri.org/publ ication detail.cfm?pubid=4073.

Wollenberg, E., D. Edmunds, and L. Buck. 2000a. Anticipating change: scenarios as a tool for adaptive forest management. Center for International Forestry Research (CIFOR), Bogor, Indonesia.

Wollenberg, E., D. Edmunds, and L. Buck. 2000b. Using scenarios to make decisions about the future: anticipatory learning for the adaptive comanagement of community forests. Landscape and Urban Planning 47(1-2):65-77.

World Bank. 2007. Tanzania country brief. The World Bank Group, Washington, D.C., USA. [online] URL: http://go.worldbank.org/7SUHE823V0 
Zeller, M., and M. Sharma. 2000. Many borrow, more save, and all insure: implications for food and micro-finance policy. Food Policy 25(4):143-167. 
Appendix 1. Dryland Farming and Small-scale Water System Tecnologies

Please click here to download file 'appendix1.pdf'. 


\section{Appendix 2. The Makanya Scenarios}

\section{Please click here to download file 'appendix2.pdf'.}

